\title{
Intraoperative model to flowmetry measurement from coronary-coronary saphenous vein graft bypass
}

\author{
LA Dallan", LAF Lisboa, OA Mejia, F Platania, F Gaiotto, A Milanez, JC Iglésias, FB Jatene \\ From 23rd World Congress of the World Society of Cardio-Thoracic Surgeons \\ Split, Croatia. 12-15 September 2013
}

\section{Background}

Late hemodynamics studies demonstrated the possibility of saphenous vein graft patency between coronary arteries that received sequential bridges, even when these grafts were completely occluded at its origin. The aim of this study was to evaluate the flowmetry of coronary-coronary saphenous vein graft.

\section{Methods}

We measured intraoperative grafts flowmetry in three patients with important retrograde flow from the coronary arteries throught saphenous vein grafts, verified after distal anastomosis. The surgeries were performed off pump. After the revascularization was completed, in the intraoperative model, we partially clamped the aorta, including both proximal veins anastomosis, and measured the flowmetry from one graft to the other. We verified the flow from vein to vein, with good myocardial perfusion.

\section{Results}

Flows and pulsatile index (PI) of the patients were: Patient 1- Flow of the circumflex coronary artery to the right coronary artery-22ml/ min,PI-4.2.Patient 2 - Flow of the right coronary artery to the left circumflex artery$54 \mathrm{ml} / \mathrm{min}, \mathrm{PI}-10.9$. Patient 3 - Flow of the circumflex artery to diagonal artery- $27 \mathrm{ml} / \mathrm{min}$, PI-3.1.

\section{Conclusion}

This is an evidence-based test that shows the possibility of obtaining flow between the coronary arteries through

\footnotetext{
* Correspondence: dcidallan@incor.usp.br Cardiovascular Surgery Department, Heart Institute (InCor), Hospital das Clínicas da Faculdade de Medicina da Universidade de São Paulo, São Paulo,
} Brazil

(c) 2013 Dallan et al; licensee BioMed Central Ltd. This is an Open Access article distributed under the terms of the Creative Commons the bypass grafts. In rare cases when patient's grafts available are not long enough to reach the usual proximal sites of arterial blood flow (ascending aorta or to make a composed graft), these evidences offer to the surgeon an alternative arterial blood source.

Published: 11 September 2013

\section{doi:10.1186/1749-8090-8-S1-P115}

Cite this article as: Dallan et al:: Intraoperative model to flowmetry measurement from coronary-coronary saphenous vein graft bypass. Journal of Cardiothoracic Surgery 2013 8(Suppl 1):P115.
Submit your next manuscript to BioMed Central and take full advantage of:

- Convenient online submission

- Thorough peer review

- No space constraints or color figure charges

- Immediate publication on acceptance

- Inclusion in PubMed, CAS, Scopus and Google Scholar

- Research which is freely available for redistribution

Submit your manuscript at www.biomedcentral.com/submit
C Biomed Central 